Vergleichende Morphologie der höheren Pflanzen

Von Prof. Dr. Wilhelm Troll. Band 1: Vegetationsorgane. Teil 1, Lieferung 3. Pp. xii +509-955. (Berlin : Gebrüder Borntraeger, 1937.) 39.50 gold marks.

$\mathrm{T}$

HE third "Lieferung" of the first part continues the large subject of branching in ferns and seedplants. Axillary branching is discussed, as also the exceptions thereto, such as epiphyllous displacement of the lateral branch, and dichotomy in palms. Accessory or supernumerary axillary shoots and their independent origin from the meristem of the axil-tissue are described. The section on the structure of lateral shoots is replete with interesting and varied examples.

Following this is an engaging account of subcotyledonary shoot-formation, instances of which are given in Linum, Linaria, Cyclamen, Orobanche, Euphorbia, etc. In the parasitic families of Orobanchaceæ, Balanophoraceæ and Raffesiaceæ hypocotyledonary and root-shoots entirely replace from the beginning the main shoot, which never exists at all in their life-history. There is a lengthy and well-illustrated chapter on the influence of symmetry conditions on branching-a very wide subject, and of far-reaching importance.

The next section deals with the orthotropous and plagiotropous growth of shoots.

A valuable and interesting section is that headed "Storage Shoots". It treats of (1) the origin and structure of rhizomes ; (2) bulbs ; (3) hypocotyledonary tubers and allied structures : amongst these are described the remarkable forms occurring in the Dioscoreacex, some of which are rhizomes, others root tubers, and still others shoot tubers; and finally (4) rhizome and stolon tubers exemplified, for example, in Stachys tuberifera, Trientalis europaea, Crepis bulbosa, Arum maculatum, Crocus, etc.

Section 7 deals with twining and tendril-forming shoots; and no one could wish for a more thorough treatment of this subject.

The final section provides a most interesting and instructive account of the form-relationships of stem-succulent plants.

The whole "Lieferung" is splendidly illustrated with photographs and drawings. W. C. WorsDell.

\section{Handbuch der Anorganischen Chemie}

In vier Bänden. Herausgegeben von Prof. Dr. R. Abegg, Dr. Fr. Auerbach und Dr. I. Koppel. Band 4, Abteilung 3: Die Elemente der achten Gruppe des periodischen Systems. Teil 2: Eisen und seine Verbindungen. A. Leiferung 3: Legierungen und Verbindungen des Eisens mit H, B, Si, P, As, Sb, Bi, S, Se, Te. Von Dr. I. Koppel. Pp. viii +559-723. (Leipzig: S. Hirzel, 1938.) 20 gold marks.

$\mathrm{T}$ HE chemistry of such a widely used and technically important element as iron is so extensive that it is not surprising that the editors of this wellknown "Handbuch" have found it necessary to divide the comprehensive study of iron and its compounds into more than one book.
It can be seen from the title that the volume under review constitutes the second part of this monograph on iron and includes the combinations of this element with some ten non-metals and metalloids. It possesses all the desirable features of comprehensiveness and simplicity in the arrangement of the subject matter, which have made Abegg justly popular among chemists. The thoroughness with which the literature has been covered may be gauged from the fact that there are references from 1718 up to the middle of 1937 , and, what is more, they can be found without difficulty.

Workers on iron will find this book invaluable within the scope of the title, and it should be on the shelves of every reference library dealing with chemical or metallurgical topics. It is printed in clear type on good paper.

\section{Beiträge zur Mineralogie von Japan} Begründet von T. Wada. Neue Folge, II. Herausgegeben von T. Ito. Pp. xii $+168+9$ plates. (Tokio, 1937.) n.p.

DROF. T. ITO, of the Mineralogical Institute of Tokyo, is continuing the excellent work begun by the late Prof. T. Wada by publishing the results of the investigation of the minerals and rocks of Japan and its dependencies. The present part is devoted to the composite sill which intrudes into the Tertiary formations near Kergan in north-eastern Korea. It is styled a sill, although the shape owing to the effect of the interposing rocks is more varied than is ordinarily understood by the term. The core consists of a syenitic rosk, above and below which is a compact syenite-dolerite.

A full and careful description is given of the rocks and the various minerals composing or associated with them. The investigation includes the study of X-ray powder diagrams of goethite and of certain pyroxenes, the diagrams being reproduced on three of the plates. The frontispiece takes the form of a plate, on which are reproduced in colour a specimen of goethite in natural size and of specimens of goethite and aegirine as seen under the microscope.

The text is in Japanese, but the book can be understood without a knowledge of this language, since the crystal forms and angular measurements are expressed in the customary manner and a good abstract in English is incorporated at the end. The alternative title-page is still retained in German.

\section{Die Chromatographische Adsorptions-methode:}

Grundlagen, Methodik, Anwendungen. Von Prof. Dr. L. Zechmeister und Dr. L. v. Cholnoky. Zweite wesentlich erweiterte Auflage. Pp. xiii +354. (Wien und Berlin : Julius Springer, 1938.) 19.80 gold marks.

IN twenty months this book, of which the first 1 edition was reviewed in Nature at some length $(140,48 ; 1937)$, has gained 125 pages-an increase of fifty per cent. This remarkable growth-rate is testimony not only to the importance of the subject, but also to the author's admirable exposition thereof. It should augur well for the success of the English edition now in preparation.

A. L. B. 